Research Article

\title{
Lack of association between genetic polymorphisms in IGF1 and IGFBP3 with twin births in a Brazilian population (Cândido Godói, Rio Grande do Sul)
}

\author{
Mariana de Oliveira-Klein ${ }^{1 *}$, Augusto César Cardoso-dos-Santos ${ }^{1 *}$ iD , Alice Tagliani-Ribeiro ${ }^{1}$, Nelson Rosa \\ Fagundes $^{1}$ (D) , Ursula Matte ${ }^{1,2,3}$ and Lavinia Schuler-Faccini ${ }^{1,2,3}$ iD \\ ${ }^{1}$ Departmento de Genética, Instituto de Bociencias, Universidade Federal do Rio Grande do Sul, Porto \\ Alegre, RS, Brazil. \\ ${ }^{2}$ Instituto Nacional de Ciência e Tecnologia de Genética Médica Populacional(INaGeMP), Departmento de \\ Genética, Instituto de Bociências, Universidade Federal do Rio Grande do Sul, Porto Alegre, RS, Brazil. \\ ${ }^{3}$ Serviço de Genética Médica, Hospital de Clínicas de Porto Alegre, Porto Alegre, RS, Brazil.
}

\begin{abstract}
Insulin-like growth factor (IGF-1) is an important peptide hormone involved in the reproduction and fetal development of mammals, and it is suggested that it may influence the human twinning rate. This study aimed to test such possible association, investigating the genetic polymorphisms IGF1 (CA)n and IGFBP3 rs2854744 in the population from Candido Godoi (CG), a small city located in the South of Brazil that has a high prevalence of twin births. A case-control study was performed comprising a total of 39 cases (representing about $40 \%$ of the mothers of twins who were born in CG after 1995) and 214 controls (mothers of non-twin children), 97 of whom were living in CG while 117 were living in Porto Alegre. DNA was extracted from blood leucocytes and genotyping was performed. According to the statistical analyses, there was no significant difference in the frequencies of both studied genetic polymorphisms when comparing case group with control group. Thus, our results pointed to a lack of association between IGF1 (CA)n and IGFBP3 rs2854744 polymorphisms and twin births in CG, but further investigations in other populations with different characteristics must be performed to confirm the role of IGF-I in human twinning.
\end{abstract}

Keywords: Insulin-like growth factor, founder effect, microsatellite, reproduction, twinning.

Received: August 24, 2017; Accepted: March 3, 2018.

\section{Introduction}

Although genetic factors related to twin births in the human species have been investigated by different approaches (Montgomery et al., 2001; Painter et al., 2010; Tagliani-Ribeiro et al., 2012; Mbarek et al., 2016), there is still a confusing scenario of which genes or alleles may be related to etiology of twinning, because it is a complex phenomenon and different causes may be involved in different situations (Lambalk et al., 1998; Huang et al., 2015; Mardini et al., 2017).

A small city in the South of Brazil, Cândido Godói (CG, latitude $27^{\circ} 45^{\prime} 07^{\prime}$, longitude $54^{\circ} 45^{\prime} 07^{\prime}$ '), has attracted the attention of researchers and curious observers due to its high rates of natural monozygotic (MZ) and dizygotic (DZ) twin births and because this trait runs among local families (Matte et al., 1996; Tagliani-Ribeiro et al., 2011). Studies previously performed in this popula-

Send correspondence to Lavinia Schuler-Faccini. Departamento de Genética, Instituto de Biociências, Universidade do Rio Grande do Sul, PO Box 15053, Campus UFRGS, 91501-970 Porto Alegre, RS, Brazil. E-mail: lavinia.faccini@ ufrgs.br

*These authors contributed equally to this work. tion have suggested that the founder effect hypothesis linked to geographical isolation may explain such peculiarity, associated to the finding of a single nucleotide polymorphism (SNP) of TP53 as a strong risk factor for twinning, possibly due to its important role in blastocyst implantation and intra utero embryo survival (TaglianiRibeiro et al., 2012). However, it is expected that other factors, including other genetic polymorphisms, contribute with the high twinning rates found in CG.

Besides the p53 pathway, factors related to individual endocrine profiles stand out as having a possible influence in twin births (Montgomery et al., 2001; Rickard et al., 2012). Insulin-like growth factor (IGF-1), for example, has previously been proposed to be associated with twin births in humans (Steinman, 2009), and biochemical and genetic studies have already related such factor to twinning in cattle (Echternkamp et al., 1990, 2004; Kim et al., 2008).

IGF-1 is an important peptide hormone for cellular differentiation and growth, and it is involved in mechanisms related to reproduction and fetal development of mammals(Adam et al., 2000; Echternkamp et al., 2004; Thomas et al., 2016). In human reproduction, IGF-1 acts as 
a pituitary regulator of follicular growth and potentiates the action of both gonadotrophins, luteinizing hormone, and follicle stimulating hormone (Ohlsson et al., 2009). In the ovary, it regulates the differentiation of granulosa cells and the development of the follicle, and may influence the twinning rate (Lambalk et al., 1998; Erickson and Shimasaki, 2001). Furthermore, traits associated with IGF-1, such as ethnicity and body mass index, vary with twinning ratio (Steinman, 2009; Rickard et al., 2012).

Genetic factors are known to influence IGF-1 levels and individual variation (Rosen et al., 1998; Kwasniewski et al., 2016). The $I G F 1$ gene has a polymorphic microsatellite of cytosine and adenine nucleotides, (CA)n, which ranges in sizes from 10 to $24 \mathrm{CA}$ repeats, located at the $I G F 1$ promoter region, approximately $1 \mathrm{~kb}$ upstream from the transcription start site (GenBank accession number AB133839.1) (Jernström et al., 2001). In the Caucasian population, the most common allele contains $19 \mathrm{CA}$ repeats (NG_011713.1:g.4248CA[19]), commonly known as (CA) 19 , which corresponds to fragments of $192 \mathrm{bp}$ after amplification (Costalonga et al., 2012). Interestingly, an exception can be found in the results by Kato et al. (2003), in which a Caucasian population presented the allele with $18 \mathrm{CA}$ repeats as the most frequent one, and the authors listed the small sample size and population admixture as possible explanations for this discrepancy. The length of CA repeats has been associated with serum IGF-1 levels and to different human phenotypes, as well as to breast and endometrial cancers (Wagner et al., 2005; Kwasniewski et al., 2016), bone disorders (Kim et al., 2002), and others (Costalonga et al., 2012; Kaczmarek et al., 2015).

In turn, the IGFBP3 gene (which synthesizes insulin-like growth factor binding protein 3 ) is responsible for transporting about $90 \%$ of the circulating IGF-1 and is capable of deregulating the levels of IGF-1 present in the plasma (Al-Zahrani et al., 2005; Ohlsson et al., 2009). There is evidence that the polymorphism rs2854744: $\mathrm{C}>\mathrm{A}$ (NG_011508.1:g.4797C > A) in IGFBP3 is a genetic factor influencing the levels of IGFBP-3 and IGF-1, and it has been shown that women homozygous for the A allele have higher levels of circulating IGFBP-3, and consequently, higher levels of circulating IGF-1 (Ali et al., 2003; AlZahrani et al., 2005; Costalonga et al., 2009; Ohlsson et al., 2009).

Taking into consideration the role of $I G F 1$ (CA)n and $I G F B P 3$ rs 2854744 polymorphisms in the metabolism of IGF-1 and in the reproductive context, the aim of this study was to investigate whether such genetic polymorphisms can help to explain the high rates of twin births found in the city of Cândido Godói, in the state of Rio Grande do Sul, Brazil.

\section{Subjects and Methods}

We designed a population-based case-control study with mothers of twins in case group and mothers of single- tons in two control groups. The study was approved by the ethics committee of the Hospital de Clínicas of Porto Alegre (HCPA) under protocol \#09-359. All procedures contributing to this work complied with the ethical standards of the relevant national and institutional committees on human experimentation and with the Helsinki Declaration of 1975, as revised in 2008 .

The case group was formed by 39 women who were mothers of twins and resided in the municipality of Cândido Godói (CG). This number represents about $40 \%$ of the mothers of twins born in CG after 1995 (Tagliani-Ribeiro et al., 2011). To compare with the case group, we studied a control group composed by 97 mothers of non-twin children born in the municipality of CG. The characteristics of both case and control groups from CG were already described in Tagliani-Ribeiro et al. (2012).

In addition, considering the common ancestral origin of the CG population, we included an external control group to determine the frequency of the investigated alleles in the state of Rio Grande do Sul consisting of 117 mothers of non-twin children living in Porto Alegre (PA), the state capital. The control group from PA had a mean age of 22.6 years and a mean number of pregnancies of 2.5 , similar to the control group from CG (Tagliani-Ribeiro et al., 2012).

Taking into account that $C G$ has an increased prevalence of both MZ and DZ twins (Matte et al., 1996; Tagliani-Ribeiro et al., 2011) and that our biological hypothesis is focused on aspects related not only to ovulation but also to fertilization and embryo development, we decided to analyze MZ and DZ twins combined.

Blood genomic DNA was extracted in accordance with Lahiri and Nurnberger (1991). For the IGF1 (CA)n polymorphism, polymerase chain reactions (PCR) were performed as described by Rosen et al. (1998), using the primer sequences 5' 5 'GCTAGCCAGCTGGTGTTATT3' and 5'ACCACTCTGGGAGAAGGGTA3'. The fragments were analyzed by capillary electrophoresis automatic sequencing in an Applied Biosystems 3500 Genetic Analyzer. In order to test the veracity of the results, one sample from each homozygote pair was sequenced for the following alleles: IGF1 (CA)19, (CA)20, (CA)21, and (CA)22. The samples were purified with the EXO I and SAP enzymes, and then subjected to Sanger sequencing. In turn, the rs 2854744 polymorphism of the IGFBP 3 gene was determined via the TaqMan SNP Genotyping Assay through allelic discrimination using the C_1842665_10 assay in accordance with the manufacturer's instructions (Applied Biosystems, USA). The reactions were conducted in the StepOnePlus PCR Real-Time System (Applied Biosystems), and the reaction products were analyzed in the StepOne v. 2.2.2 software.

The Hardy-Weinberg equilibrium was calculated using version 3.11 of the Arlequin program. Simple comparisons of IGF1 allelic frequencies in the cases and controls were done using the $G$-Test (likelihood ratio chi-square), 
with a $95 \%$ confidence interval, in version 11.15 of the WinPEPI program. For analysis of the IGFBP 3 gene, the two-tailed Fisher's exact test and Pearson's chi-square tests were used to compare the allelic and genotypic frequencies between case and control groups using IBM SPSS v.18.0 software (IBMCorp., Armonk, NY).

\section{Results}

The case and control groups were in Hardy-Weinberg equilibrium for both of the polymorphisms tested ( $p>$ 0.05 ). The analyses of the $I G F 1$ (CA)n polymorphism revealed eight different alleles in CG, varying from 11 to 22 CA repeats (Table 1). In turn, alleles with 23 and 24 CA repeats (with 200 and $202 \mathrm{bp}$, respectively) were found in Porto Alegre, but at a low frequency. In all studied populations, the most frequent allele was that with $19 \mathrm{CA}$ repeats, and $192 \mathrm{bp}$. Although the allele with 22 CA repeats (198 bp) occurred more frequently in the mothers of twins $(7.7 \%)$ than in both control groups, there was no statistical significance in the distribution of $I G F I$ (CA)n between case and control groups from CG $(p=0.182)$ and from PA $(p=0.065)$. Similarly, for the IGFBP 3 rs 2854744 polymorphism, there was no statistically significant difference between case and control groups, both for allelic and genotypic frequencies (Table 2).

\section{Discussion}

Although IGF-1 has been considered an important factor in the understanding of human twinning (Steinman, 2009), we did not find a statistical association between two genetic polymorphisms commonly related to metabolism in a population with a very peculiar founding history and that shows increased rates of twin births (Matte et al., 1996; Tagliani-Ribeiro et al., 2011).

Interestingly, upon analyzing the results obtained in studies of the IGF1 (CA)n polymorphism in various continents (Table 3), the frequency of the allele with 22 repeats was found to be low, ranging from $1.5 \%$ in European popu-

Table 1 - Frequency of IGFI (CA)n polymorphism in cases and controls.

\begin{tabular}{|c|c|c|c|c|c|c|c|c|}
\hline \multirow[t]{3}{*}{ Number of $\mathrm{CA}^{\mathrm{a}}$ repeats } & \multirow{2}{*}{\multicolumn{2}{|c|}{$\begin{array}{c}\text { Cases } \\
(\mathrm{n}=39)\end{array}$}} & \multicolumn{4}{|c|}{$\mathrm{CG}^{\mathrm{b}}$ controls } & \multirow{2}{*}{\multicolumn{2}{|c|}{$\begin{array}{c}\mathrm{PA}^{\mathrm{c}} \text { controls } \\
(\mathrm{n}=117)\end{array}$}} \\
\hline & & & & & & & & \\
\hline & $\mathrm{N}$ & $\%$ & $\mathrm{~N}$ & $\%$ & $\mathrm{p}^{\mathrm{d}}$ & $\mathrm{N}$ & $\%$ & $\mathrm{p}^{\mathrm{d}}$ \\
\hline 11 & - & - & 1 & 0.5 & 0.55 & 1 & 0.4 & 0.55 \\
\hline 16 & - & - & 2 & 1.0 & 0.40 & 2 & 0.9 & 0.40 \\
\hline 17 & 1 & 1.3 & 3 & 1.5 & 0.66 & 3 & 1.3 & 0.97 \\
\hline 18 & 4 & 5.1 & 15 & 7.8 & 0.37 & 21 & 9.0 & 0.25 \\
\hline 19 & 50 & 64.1 & 112 & 57.8 & 0.31 & 148 & 63.2 & 0.75 \\
\hline 20 & 13 & 16.7 & 47 & 24.2 & 0.13 & 29 & 12.4 & 0.38 \\
\hline 21 & 4 & 5.1 & 11 & 5.7 & 0.86 & 26 & 11.1 & 0.10 \\
\hline 22 & 6 & 7.7 & 3 & 1.5 & 0.01 & 2 & 0.9 & $<0.001$ \\
\hline 23 & - & - & - & - & - & 1 & 0.4 & 0.55 \\
\hline 24 & - & - & - & - & - & 1 & 0.4 & 0.55 \\
\hline Total & 78 & 100 & 194 & 100 & 0.18 & 234 & 100 & 0.07 \\
\hline
\end{tabular}

${ }^{\mathrm{a}} \mathrm{CA}$ : cytosine-adenosine; ${ }^{\mathrm{b}} \mathrm{CG}$ : Cândido Godói; ${ }^{\mathrm{c}} \mathrm{PA}$ : Porto Alegre; ${ }^{\mathrm{d}} G$-test

Table 2 - Frequency of $I G F B P 3$ rs 2854744 gene polymorphism in cases and controls.

\begin{tabular}{|c|c|c|c|c|c|c|c|c|}
\hline \multirow[t]{2}{*}{ Allele } & \multicolumn{2}{|c|}{$\begin{array}{c}\text { Cases } \\
(\mathrm{n}=39)\end{array}$} & \multicolumn{2}{|c|}{$\begin{array}{c}\mathrm{CG}^{\mathrm{a}} \text { controls } \\
(\mathrm{n}=97)\end{array}$} & \multirow[t]{2}{*}{$\mathrm{p}^{\mathrm{c}}$} & \multicolumn{2}{|c|}{$\begin{array}{l}\text { PAb controls } \\
\quad(\mathrm{n}=117)\end{array}$} & \multirow[t]{2}{*}{$p^{c}$} \\
\hline & $\mathrm{N}$ & $\%$ & $\mathrm{~N}$ & $\%$ & & $\mathrm{~N}$ & $\%$ & \\
\hline $\mathrm{C}$ & 44 & 56.4 & 104 & 53.6 & 0.689 & 112 & 47.9 & 0.239 \\
\hline $\mathrm{A}$ & 34 & 43.6 & 90 & 46.4 & & 122 & 52.1 & \\
\hline Genotype & $\mathrm{N}$ & $\%$ & $\mathrm{~N}$ & $\%$ & $p^{d}$ & $\mathrm{~N}$ & $\%$ & $p^{d}$ \\
\hline $\mathrm{CC}$ & 14 & 35.9 & 32 & 33.0 & & 32 & 27.4 & \\
\hline $\mathrm{CA}$ & 16 & 41.0 & 40 & 41.2 & 0.927 & 48 & 41.0 & 0.484 \\
\hline $\mathrm{AA}$ & 9 & 23.1 & 25 & 25.8 & & 37 & 31.6 & \\
\hline
\end{tabular}

${ }^{\mathrm{a}} \mathrm{CG}$ : Cândido Godói; ${ }^{\mathrm{b}} \mathrm{PA}$ : Porto Alegre; 'Two-tailed Fisher's exact test; ${ }^{\mathrm{d}}$ Pearson's chi-square test 


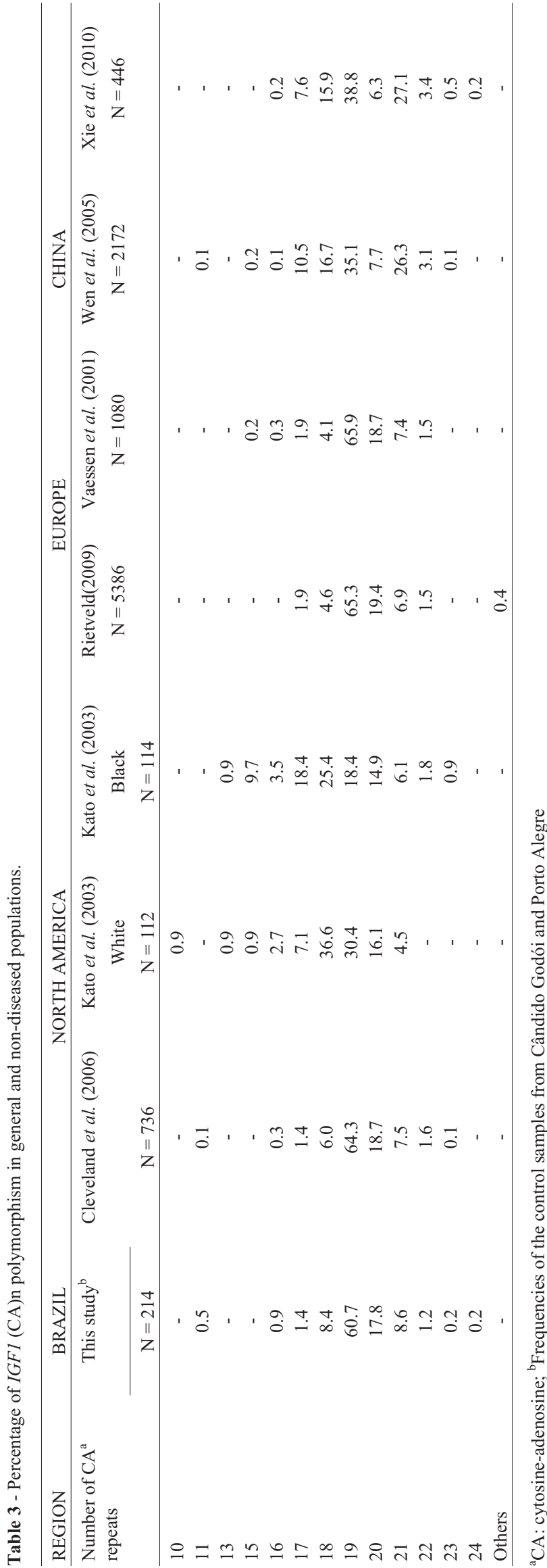

lations (Vaessen et al., 2001; Rietveld, 2009) to 3.4\% in a study conducted in China (Xie et al., 2010). In the case group of the present study, this allele occurred at a frequency of $7.7 \%$, while in the controls from both CG and $\mathrm{PA}$, these frequencies were similar to those observed in studies conducted in Europe and North America (Vaessen et al., 2001; Kato et al., 2003; Wen et al., 2005; Cleveland et al., 2006; Rietveld, 2009).

In conclusion, our results indicate a lack of association between twin births in CG and polymorphisms IGFI (CA)n and IGFBP3 rs2854744. Unfortunately, we could not assess serum IGF-1 levels and compare these with the investigated genetic polymorphisms. However, genetic variants related to such factors have been independently associated with several different phenotypes (Wagner et al., 2005; Cleveland et al., 2006; Kaczmarek et al., 2015). Furthermore, to the best of our knowledge, this is the first study to investigate the IGFI (CA)n and IGFBP3 rs2854744 polymorphisms in human twinning. Further investigations in other populations with different characteristics should be performed to better understand the role of IGF-1 in human twin births.

\section{Acknowledgments}

The authors thank the community of Cândido Godói for their hospitality, especially the twins and their families. The authors acknowledge to INAGEMP (grant number CNPq 573993/2008-4) for financial support.

\section{References}

Adam CL, Gadd TS, Findlay PA and Wathes DC (2000) IGF-I stimulation of luteinizing hormone secretion, IGF-binding proteins (IGFBPs) and expression of mRNAs for IGFs, IGF receptors and IGFBPs in the ovine pituitary gland. J Endocrinol 166:247-254.

Al-Zahrani A, Sandhu MS, Luben RN, Thompson D, Baynes C, Pooley KA, Luccarini C, Munday H, Perkins B, Smith P et al. (2005) IGF1 and IGFBP3 tagging polymorphisms are associated with circulating levels of IGF1, IGFBP3 and risk of breast cancer. Hum Mol Genet 15:1-10.

Ali O, Cohen P and Lee KW (2003) Epidemiology and biology of insulin-like growth factor binding protein-3 (IGFBP-3) as an anti-cancer molecule. Horm Metab Res 35:726-733.

Cleveland RJ, Gammon MD, Edmiston SN, Teitelbaum SL, Britton JA, Terry MB, Eng SM, Neugut AI, Santella RM and Conway K (2006) IGF1 CA repeat polymorphisms, lifestyle factors and breast cancer risk in the Long Island Breast Cancer Study Project. Carcinogenesis 27:758-765.

Costalonga EF, Antonini SR, Guerra-Junior G, Mendonca BB, Arnhold IJP and Jorge AAL (2009) The -202 A allele of insulin-like growth factor binding protein-3 (IGFBP3) promoter polymorphism is associated with higher IGFBP-3 serum levels and better growth response to growth hormone treatment in patients with severe growth hormone deficiency. J Clin Endocrinol Metab 94:588-595.

Costalonga EF, Antonini SRR, Guerra-Junior G, Coletta RRD, Franca MM, Braz AF, Mendonca BB, Arnhold IJP and Jorge 
AAL (2012) Growth hormone pharmacogenetics: The interactive effect of a microsatellite in the IGF1 promoter region with the GHR-exon 3 and -202 A/C IGFBP3 variants on treatment outcomes of children with severe GH deficiency. Pharmacogenomics J 12:439-445.

Echternkamp SE, Spicer LJ, Gregory KE, Canning SF and Hammond JM (1990) Concentrations of insulin-like growth factor-I in blood and ovarian follicular fluid of cattle selected for twins. Biol Reprod 43:8-14.

Echternkamp SE, Roberts AJ, Lunstra DD, Wise T and Spicer LJ (2004) Ovarian follicular development in cattle selected for twin ovulations and births. J Anim Sci 82:459-471.

Erickson GF and Shimasaki S (2001) The physiology of folliculogenesis: the role of novel growth factors. Fertil Steril 76:943-949.

Huang H, Clancy KBH, Burhance C, Zhu Y and Madrigal L (2015) Women who deliver twins are more likely to smoke and have high frequencies of specific SNPs: Results from a sample of African-American women who delivered preterm, low birth weight babies. Am J Hum Biol 27:605-612.

Jernström H, Deal C, Wilkin F, Chu W, Tao Y, Majeed N, Hudson T, Narod SA and Pollak M (2001) Genetic and nongenetic factors associated with variation of plasma levels of insulin-like growth factor-I and insulin-like growth factorbinding protein-3 in healthy premenopausal women. Cancer Epidemiol Biomarkers Prev 10:377-384.

Kaczmarek M, Pacholska-Bogalska J, Kwasniewski W, Kotarski J, Halerz-Nowakowska B and Gozdzika-Józefiak A (2015) A microsatellite polymorphism in IGF1 gene promoter and timing of natural menopause in Caucasian women. Int J Med Sci 12:32-41.

Kato I, Eastham J, Li B, Smith M and Yu H (2003) Genotype-phenotype analysis for the polymorphic CA repeat in the insulin-like growth factor-I (IGF-I) gene. Eur J Epidemiol 18:203-209.

Kim ES, Shi X, Cobanoglu O, Weigel K, Berger PJ and Kirkpatrick BW (2008) Refined mapping of twinning-rate quantitative trait loci on bovine chromosome 5 and analysis of insulin-like growth factor-1 as a positional candidate gene. J Anim Sci 87:835-843.

Kim JG, Roh KR and Lee JY (2002) The relationship among serum insulin-like growth factor-I, insulin-like growth factor-I gene polymorphism, and bone mineral density in postmenopausal women in Korea. Am J Obstet Gynecol 186:345-350.

Kwasniewski W, Gozdzicka-Jozefiak A, Wolun-Cholewa M, Polak G, Sierocinska-Sawa J, Kwasniewska A and Kotarski J (2016) Microsatellite polymorphism in the P1 promoter region of the IGF-1 gene is associated with endometrial cancer. Mol Med Rep 13:4950-4958.

Lahiri DK and Nurnberger JI (1991) A rapid non-enzymatic method for the preparation of HMW DNA from blood for RFLP studies. Nucleic Acids Res 19:5444.

Lambalk CB, Boomsma DI, De Boer L, De Koning CH, Schoute E, Popp-Snijders C and Schoemaker J (1998) Increased levels and pulsatility of follicle-stimulating hormone in mothers of hereditary dizygotic twins. J Clin Endocrinol Metab 83:481-486.

Mardini AC, Pereira FS, Schuler-Faccini L and Matte U (2017) Analysis of polymorphism rs1042522 in TP53 gene in the mothers of twins and of singletons: A population-based study in Rio Grande do Sul, Brazil. Twin Res Hum Genet 20:132-136.

Matte U, Le Roux MG, Bénichou B, Moisan JP and Giugliani R (1996) Study on possible increase in twinning rate at a small village in south Brazil. Acta Genet Med Gemellol (Roma) 45:431-437.

Mbarek H, Steinberg S, Nyholt DR, Gordon SD, Miller MB, McRae AF, Hottenga JJ, Day FR, Willemsen G, de Geus EJ et al. (2016) Identification of common genetic variants influencing spontaneous dizygotic twinning and female fertility. Am J Hum Genet 98:898-908.

Montgomery GW, Duffy DL, Hall J, Kudo M, Martin NG and Hsueh AJ (2001) Mutations in the follicle-stimulating hormone receptor and familial dizygotic twinning. Lancet 357:773-774.

Ohlsson C, Mohan S, Sjögren K, Tivesten Å, Isgaard J, Isaksson O, Jansson JO and Svensson J (2009) The Role of liverderived insulin-like growth factor-I. Endocr Rev 30:494-535.

Painter JN, Willemsen G, Nyholt D, Hoekstra C, Duffy DL, Henders AK, Wallace L, Healey S, Cannon-Albright LA, Skolnick M et al. (2010) A genome wide linkage scan for dizygotic twinning in 525 families of mothers of dizygotic twins. Hum Reprod 25:1569-1580.

Rickard IJ, Prentice AM, Fulford AJC and Lummaa V (2012) Twinning propensity and offspring in utero growth covary in rural African women. Biol Lett 8:67-70.

Rietveld I (2009) The Role of a CA repeat polymorphism in the promoter region of the Insulin-like Growth Factor-I gene in physiology and the pathophysiology of diabetes mellitus. Erasmus University Rotterdam, Rotterdam, 126 p.

Rosen CJ, Kurland ES, Vereault D, Adler RA, Rackoff PJ, Craig WY, Witte S, Rogers J and Bilezikian JP (1998) Association between serum insulin growth factor-I (IGF-I) and a simple sequence repeat in IGF-I gene: implications for genetic studies of bone mineral density. J Clin Endocrinol Metab 83:2286-2290.

Steinman G (2009) Why the twinning rate is higher in Africa than elsewhere: An analysis of selected factors. J Reprod Med 54:609-616.

Tagliani-Ribeiro A, Oliveira M, Sassi AK, Rodrigues MR, Zagonel-Oliveira M, Steinman G, Matte U, Fagundes NJR and Schuler-Faccini L (2011) Twin town in South Brazil: A Nazi's experiment or a genetic founder effect? PLoS One 6:e20328.

Tagliani-Ribeiro A, Paskulin DD, Oliveira M, Zagonel-Oliveira M, Longo D, Ramallo V, Ashton-Prolla P, Saraiva-Pereira ML, Fagundes NJR, Schuler-Faccini L et al. (2012) High twinning rate in Cândido Godói: A new role for p53 in human fertility. Hum Reprod 27:2866-2871.

Thomas N, Venkatachalapathy T, Aravindakshan T and Raghavan KC (2016) Molecular cloning, SNP detection and association analysis of 5' flanking region of the goat IGF1 gene with prolificacy. Anim Reprod Sci 167:8-15.

Vaessen N, Heutink P, Janssen JA, Witteman JC, Testers L, Hofman A, Lamberts SW, Oostra BA, Pols HA and van Duijn CM (2001) A polymorphism in the gene for IGF-I: Functional properties and risk for type 2 diabetes and myocardial infarction. Diabetes 50:637-642.

Wagner K, Hemminki K, Israelsson E, Grzybowska E, Söderberg M, Pamula J, Pekala W, Zientek H, Mielzynska D, Siwinska 
E et al. (2005) Polymorphisms in the IGF-1 and IGFBP3 promoter and the risk of breast cancer. Breast Cancer Res Treat 92:133-140.

Wen W, Gao YT, Shu XO, Yu H, Cai Q, Smith JR and Zheng W (2005) Insulin-like growth factor-I gene polymorphism and breast cancer risk in Chinese women. Int $\mathrm{J}$ Cancer 113:307-311.
Xie L, Gong YY, Lian SG, Yang J, Gao SJ, Xu LY and Zhang YP (2010) A microsatellite polymorphism in IGF1 gene promoter and longevity in a Han Chinese population. BMC Res Notes 3:55.

Associate Editor: Maria Luiza Petzl-Erler

License information: This is an open-access article distributed under the terms of the Creative Commons Attribution License (type CC-BY), which permits unrestricted use, distribution and reproduction in any medium, provided the original article is properly cited. 